\title{
Immune mechanisms of childhood asthma
}

\author{
Carolyn E Donovan, Patricia W Finn
}

Asthma is the most common chronic disease of childhood in developed countries. ${ }^{1}$ Recent studies suggest that most asthmatics are diagnosed by the age of five, with symptoms first occurring during infancy and early childhood. ${ }^{2}{ }^{3}$ Allergy is known to play a significant role in childhood asthma. ${ }^{4-6}$ The prevalence of allergic diseases including asthma has increased significantly over the past 40 years. $^{78}$ The reasons for this increase are not known but are under active investigation. Understanding the pathogenesis of childhood asthma may lead to the development of novel therapies or even to preventive strategies. Little is known about the cellular and molecular mechanisms underlying this disorder. $T$ cells are critical for the initiation and maintenance of the mature asthmatic inflammatory response. Complex interactions between $\mathrm{T}$ and $\mathrm{B}$ lymphocytes and antigen presenting cells (APC) lead to inflammation, cytokine production, IgE production, and bronchial hyperresponsiveness (BHR). T cell differentiation which will lead to expression of the asthmatic phenotype probably occurs in early childhood under the influence of complex genetic and environmental factors. This review will focus on current knowledge about immune mechanisms of childhood asthma in developed countries. Topics to be discussed include the role of $\mathrm{T}$ cells in asthma, maternal-fetal immunological interactions which may promote atopy, the importance of allergens, the antibody response to allergens in early life, $T$ cell function and allergen specific $T$ cell immunity in neonates, cytokine profiles of neonatal lymphocytes, and potential strategies for prevention of childhood asthma.

\section{Role of $T$ cells in asthma}

$\mathrm{T}$ cells are critical to the pathogenesis of allergic asthma in adults. ${ }^{9-11}$ Chronically activated $\mathrm{T}$ memory cells sensitised against a variety of allergens are believed to be responsible for the maintenance of airway inflammation. ${ }^{11}$ Soluble interleukin (IL)-2 receptor levels are raised in children with asthma, suggesting that activated $\mathrm{T}$ cells are important in childhood asthma as well. ${ }^{12}$ Current data support the predominance of a T helper 2 phenotype in allergic asthma. ${ }^{13-21}$ Allergens induce CD4+ $\mathrm{T}$ helper cells to produce type 2 (Th2) cytokines such as IL-4, IL-5, IL-6, IL-10, and IL-13. IL-5 attracts and activates eosinophils, while IL- 4 is essential for B cell isotype switching to IgE. CD8+ T cells may lead to IgE class switching via IL-13 rather than IL-4. ${ }^{22}$ These events lead to eosinophilic bron- chitis, mucus hypersecretion, and bronchial smooth muscle contraction. ${ }^{23}$ However, some studies suggest that $\mathrm{T}$ helper type 1 (Th1) cytokines such as IL-2, interferon gamma (IFN$\gamma)$, tumour necrosis factor alpha (TNF- $\alpha$ ), and IL-15 may promote allergic airway inflammation as well. ${ }^{24}{ }^{25}$ Thus, asthma as a paradigm of an exclusively Th 2 mediated disease may not take into account all the complexities involved in its pathobiology.

Complete activation of $\mathrm{T}$ cells requires an antigen specific signal transduced by the $\mathrm{T}$ cell receptor and an antigen non-specific costimulatory signal (fig 1 ). ${ }^{26} \mathrm{~T}$ cell receptor signals without co-stimulation result in a state of prolonged inactivation or anergy. ${ }^{27}$ The best characterised co-stimulatory pathway is the CD28/B7 pathway. CD28 is constitutively expressed on T cells and binds to B7-1 (CD80) and B7-2 (CD86) on APC. Engagement of the $\mathrm{T}$ cell receptor plus co-stimulation through CD28 leads to full $\mathrm{T}$ cell activation. CTLA4, a B7 counter-receptor which is upregulated after activation, is presumed to be a negative regulator of $\mathrm{T}$ cell activation. ${ }^{28-31}$ Additional costimulatory molecules include ICOS and CD40/CD40 ligand (CD40L). ICOS is structurally homologous to CD28 but is upregulated after $\mathrm{T}$ cell activation. ${ }^{32}$ Activated $\mathrm{T}$ cells express CD40L which engages CD40 on APC and induces them to produce cytokines such as IL-12. ${ }^{33}$ IL-12 induces dendritic cells, monocytes, and natural killer cells to produce IFN- $\gamma$, thus promoting a Th1 effector response. Less well characterised co-stimulatory molecules such as intercellular adhesion molecule 1, $4-1 \mathrm{BB}$, and heat stable antigen are currently being studied. ${ }^{34-38}$

Murine models have provided strong evidence for the role of $\mathrm{T}$ cell activation in asthma. ${ }^{39}$ In these models systemic sensitisation to an allergen followed by aerosolised allergen challenge lead to features characteristic of human asthma. Inhibition of CD28/B7 co-stimulation diminishes allergic pulmonary inflammation. CTLA4-Ig is a fusion protein composed of a soluble form of CTLA4 linked to the Fc portion of human IgG1. ${ }^{40}$ It inhibits CD28/B7 co-stimulation by binding B7 molecules on the cell surface. In a murine model of allergen induced airway inflammation, treatment with CTLA4-Ig during aerosolised allergen challenge significantly lowered BHR, serum IgE, airway inflammatory cells, and thoracic $\mathrm{T}$ cell activation, originally shown by Krinzman et $a l^{41}$ and subsequently confirmed 


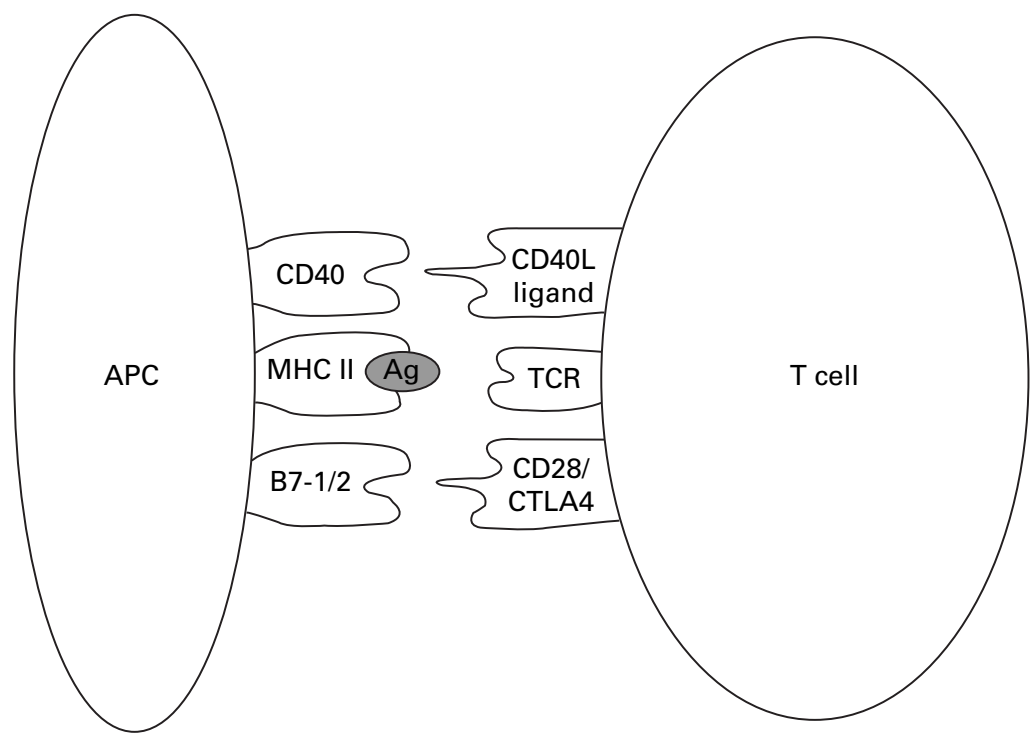

Figure 1 Co-stimulatory pathways of $T$ cell activation. Complete activation of $T$ cells requires at least two signals: (1) the interaction of the $T$ cell receptor (TCR) with antigen (Ag)/major histocompatibility complex class II (MHC II) on the antigen presenting cell $(A P C)$ and (2) an antigen non-specific co-stimulatory signal. The best characterised co-stimulatory pathway is the CD28/B7 pathway. CD28 is constitutively expressed on $T$ cells and binds to B7-1 or B7-2 on APC. CTLA4, another B7 counter-receptor, is upregulated after $T$ cell activation and is presumed to be a negative regulator of $T$ cell activation. Activated T cells express other co-stimulatory molecules including CD40 ligand (CD40L) which engages CD40 on APC and may upregulate B7 molecule expression.

by others. ${ }^{42-44}$ Selective blockade of either B7-1 or B7-2 in allergen sensitised and challenged mice similarly inhibited pulmonary inflammation and $\mathrm{BHR}$, indicating the importance of both $\mathrm{B} 7$ molecules. ${ }^{45}$ B7-1 and B7-2 appear necessary for the induction of airway eosinophilia. ${ }^{44}{ }^{46}$ B7-2 has been implicated in allergen induced $\mathrm{T}$ cell activation and IL-5 production in human asthmatic airways. ${ }^{47}$ Alveolar macrophages from asthmatics overexpress B7-2 and B7-1. ${ }^{48}$ The effectiveness of CD28/B7 blockade prior to aerosolised allergen challenge suggests that $\mathrm{T}$ cell costimulation may be essential not only for allergen sensitisation but also for the generation and maintenance of the allergic response when allergens are re-encountered. If so, treatments aimed at inhibition of $\mathrm{T}$ cell co-stimulation may be effective in childhood asthma even after allergic sensitisation has already occurred.

\section{Maternal-fetal immunological}

\section{interactions and childhood asthma}

Epidemiological data showing associations between various maternal factors and childhood asthma have spurred interest in understanding how the intrauterine environment might influence the fetal and neonatal immune response to allergens. ${ }^{49} 50$ Maternal factors associated with an increased risk of childhood asthma include younger age, ${ }^{51-53}$ smoking, ${ }^{54-56}$ lack of prenatal care, and weight gain of less than $20 \mathrm{lbs}(9.1 \mathrm{~kg})$ during pregnancy. ${ }^{56} \mathrm{~A}$ maternal history of allergy or asthma is more strongly associated with atopy in children than a paternal history, suggesting that maternal influences on childhood asthma are not exclusively genetic ones. ${ }^{57-61}$ Maternal antibodies, the intrauterine cytokine milieu, or transplacental transfer of antigens may promote allergic sensitisation in the fetus. ${ }^{586263}$
It has been hypothesised that atopy in children represents the persistence of prenatal and neonatal allergen specific Th2 responses due to failure of immune deviation mechanisms which promote the Th1 state of the normal adult immune system. ${ }^{64}$ There is evidence both in murine and human studies that during pregnancy the maternal immune response is of the Th2 type, as Th1 type cell mediated immune responses are potentially harmful to the maintenance of pregnancy. ${ }^{65-68}$ Pregnant women have compromised cell mediated immunity, ${ }^{69}$ impaired lymphocyte proliferation, ${ }^{70}$ and loss of peripheral blood mononuclear cell (PBMC) proliferative responses to recall antigens. ${ }^{71}$ However, maternal $\mathrm{T}$ cells recognise paternally inherited fetal antigens. Production of anti-HLA antibodies in normal pregnancy may be a Th2 immune response to paternal antigens; absence of these antibodies in women with spontaneous abortions is associated with a Th1 autoimmune response. $^{68}$ The fetal trophoblast expresses low affinity receptors for Th1 cytokines, resulting in a preference for Th2 responses at the maternalfetal interface. ${ }^{72}{ }^{73} \mathrm{IL}-4$ is produced by human amnion epithelium, and IL-10 mRNA has been detected in human placental tissue. ${ }^{74}$ In summary, current data suggest that successful pregnancy requires a Th2 biased maternal immune response. Whether this prenatal Th2 bias persists and promotes the development of hypersensitivity to environmental allergens in some infants, thus predisposing them to asthma, has yet to be determined.

Early postnatal factors such as breast feeding and sites of antigen presentation may also effect the neonate's immune response in important ways. $^{76}$ There was decreased rejection and better graft function at one year in children who received a renal transplant from their mother and were breast fed compared with children who were not breast fed, suggesting that exposure to maternal allogeneic cells during breast feeding led to donor specific hyporesponsiveness in the neonate. ${ }^{77}$ Relative to sites of antigen presentation, mucosal dendritic cells are important APCs in the airway and are known to promote Th2 biased responses. ${ }^{78} 79$ Thus, both prenatal and postnatal factors should be considered as potentially influencing the immune response to allergens in early life.

\section{Role of allergens in childhood asthma}

Asthma associated allergens in developed countries are primarily perennial indoor allergens such as house dust mite (HDM), animal dander, and cockroaches. ${ }^{80-84}$ Increased exposure to indoor allergens may be relevant to the recent increased incidence and severity of asthma in children. ${ }^{6}$ Most clinical studies support the hypothesis that allergy plays a major role in the pathogenesis of childhood asthma. ${ }^{4}$ By the age of six, children who wheezed had significantly more positive skin tests to aeroallergens than children who never wheezed. ${ }^{61}$ Risk factors for childhood asthma consistently include allergen exposure and allergy. ${ }^{85} 86$ Higher cockroach allergen levels in the home have been associated with a significantly increased risk of developing asthma in children 
younger than five years old in Boston (G Litonjua, 1999, personal communication). The age of onset of asthma in children of atopic parents and the risk of sensitised children developing BHR is related to the level of HDM exposure. ${ }^{82} 8788$ Zimmerman et al found a linear relation between the number of positive skin tests and the severity of asthma in children older than six. ${ }^{89}$ Other investigators have confirmed a relationship between atopy and the severity of asthma symptoms and BHR. ${ }^{50} 91$ The age at which allergic sensitisation occurs is important: children who become sensitised in infancy or early childhood are at higher risk of developing asthma than those who become sensitised later. ${ }^{90}{ }^{92}$ Studies performed in developing countries have shown less of an association between sensitisation to indoor allergens and asthma. ${ }^{93}{ }^{94}$ Thus, while allergen exposure and allergic sensitisation increase a child's risk of developing asthma, the molecular mechanisms leading to airway inflammation and BHR in some but not all sensitised children have yet to be elucidated. The type and kinetics of allergen exposure, for example, might account for some of the geographical differences seen in the prevalence of allergy and asthma.

Fetal immunoglobulin production and the antibody response to environmental allergens in the perinatal period

Immune responses to allergens early in life, perhaps even in utero, may be critical to the pathogenesis of childhood asthma. There is therefore great interest in understanding the fetal, neonatal, and early childhood immune response to antigens, particularly to inhaled allergens. Production of IgM, IgG subclasses and IgE in response to $\mathrm{T}$ cell derived activation signals - for example, CD40 and cytokines, is similar in neonatal B cells and antigenically naive adult B cells. ${ }^{95}{ }^{96}$ Fetal B cells are capable of isotype switching. ${ }^{97} 98 \mathrm{~T}$ cell dependent isotype switching and immunoglobulin production for certain pathogens such as toxoplasmosis can occur in a fetus; however, other congenital infections such as varicella zoster virus do not induce specific immunoglobulin by birth or early childhood. ${ }^{99}{ }^{100}$ Impaired fetal and neonatal $\mathrm{B}$ cell responses may be due to reduced production of $T$ cell cytokines such as $\mathrm{CD} 40 \mathrm{~L}$ or to reduced function of neonatal dendritic cells. ${ }^{101} 102$

Immune responses to airborne environmental antigens in the perinatal period may be a universal phenomenon and a necessary determinant of the asthmatic phenotype later in life. In one study children produced $\operatorname{IgG}_{1}$ antibodies but not $\mathrm{IgG}_{4}$ antibodies against an inhaled allergen between three and 12 months of age ${ }^{103}$; data suggest that $\operatorname{IgG}_{4}$ antibodies increase with age ${ }^{104}$ although the majority of the studies were not performed prospectively. ${ }^{105-107}$ Antibodies to inhaled allergens start to rise significantly at the age of two and reach levels comparable to those of adulthood by the age of five. ${ }^{104}$ In contrast, the antibody response to dietary allergens such as ovalbumin (OVA) occurs during the first two years and generally disappears by the age of five. ${ }^{104}{ }^{108}$ Young children with atopic dermatitis have higher levels of antibodies to dietary allergens, while young children with asthma or allergic rhinitis have higher levels of antibodies to inhaled allergens. ${ }^{108}$ Some studies have found that an increased cord blood level of IgE is associated with an increased risk of atopy or asthma in childhood ${ }^{57} 109110$ while other studies have not confirmed this association. ${ }^{6111}$ An increased cord blood level of IgE and family history of atopy do not have sufficient sensitivity or specificity to predict subsequent atopy. ${ }^{112} \operatorname{IgE}$ responses to inhaled allergens are usually detectable by 2-3 years of age and tend to disappear by the age of $5-6$, although they persist and increase in some children. ${ }^{113-115}$ An increased serum IgE level during the first year of life or at the age of six is associated with wheezing. ${ }^{61}$ Almost all adults have serum antibodies against common environmental allergens; atopy is associated with the presence of allergen specific IgE antibodies. ${ }^{106} 107116$

\section{$T$ cell function in neonates}

Lymphocytes are first observed in the fetal thymus at 8-9 weeks of gestation and migrate to the circulation at about 14-16 weeks. After 22 weeks gestation most circulating $T$ cells are of the naive (CD45RA high CD45RO low) phenotype. ${ }^{117} 118$ In most studies third trimester fetuses and neonates do not have circulating memory (CD45RO high) $\mathrm{T}$ cells; gradual increases in the proportion of memory $\mathrm{T}$ cells and their production of cytokines such as IFN- $\gamma$ are likely due to increasing antigenic exposure and $\mathrm{T}$ cell activation. ${ }^{101}{ }^{119-121}$ Both neonatal $\mathrm{T}$ cells and adult naive $\mathrm{T}$ cells have a reduced capacity to proliferate and produce cytokines compared with memory or effector $T$ cells, suggesting that deficiencies of neonatal $\mathrm{T}$ cell function may be due in part to lack of antigenic experience. ${ }^{101}$

Antigen specific proliferation and cytokine production following congenital or postnatal infections are usually reduced in neonates compared with older children and adults, perhaps due to defects in $\mathrm{T}$ cell activation, co-stimulation, or antigen processing. ${ }^{99} 122123$ Naive cord blood $T$ cells are more difficult to activate in vitro than naive adult peripheral blood $\mathrm{T}$ cells and have an impaired ability to translate IL-2 mRNA, a cytokine which stimulates $\mathrm{T}$ cell proliferation. ${ }^{124}{ }^{125}$ Some studies have found that neonatal $\mathrm{T}$ cells have a reduced capacity to express CD40L, ${ }^{126-128}$ while other data suggest that CD40L expression is comparable in neonatal and adult T cells. ${ }^{129} \mathrm{CD} 40 \mathrm{~L}$ expression during antigen specific $\mathrm{T}$ cell activation in neonates has not yet been characterised. Cayabyab et al found that CD28mediated co-stimulation is similar in neonatal and adult $\mathrm{T}$ cells ${ }^{130}$; in contrast, another study suggests that neonatal $\mathrm{T}$ cells may require co-stimulatory signals in addition to CD28. ${ }^{131}$ The requirement for additional co-stimulatory signals in the neonate may be related to low levels of inducible NF- $\kappa \mathrm{B}$, a transcription factor which upregulates IL-2 gene transcription. ${ }^{131}$ There are age dependent differences in $\mathrm{T}$ helper and antigen presenting functions. ${ }^{132}$ The fetal immune system has deficiencies in 
accessory cell function necessary for $\mathrm{T}$ cell activation. Neonatal dendritic cell immaturity may be a factor in the development of allergic disease, as dendritic cells are important APCs in airway epithelium. ${ }^{76} 131{ }^{133-135}$ Agea et al found that HDM allergen or Th2 cytokines upregulated B7-2 expression on cord blood APCs from infants without a family history of atopy. ${ }^{48}$ It will be interesting to determine whether co-stimulatory molecule expression on neonatal dendritic cells promote hypersensitivity to inhaled allergens or tolerance, a state of antigen specific unresponsiveness.

In summary, $T$ cell functions in the fetus and neonate which are impaired compared with adults include cell mediated cytotoxicity, antigen specific cytokine production, help for B cell antibody responses, upregulation of some co-stimulatory molecules (such as CD40L), and antigen presentation. ${ }^{64}$ Fetal and neonatal $B$ cells have the capacity to be activated and undergo isotype switching but may be more susceptible to tolerance induction. The deficiencies of the neonatal immune system may reflect lack of previous antigenic exposure since neonatal and adult naive lymphocytes share many characteristics. ${ }^{101}$ Further elucidation of how the immune response develops in early life will lay the groundwork for understanding how pathological responses to environmental allergens occur.

\section{Development of allergen specific $T$ cell immunity in neonates}

Prospective studies on peripheral blood T cell reactivity to different allergens in fetuses, infants, and young children have been initiated in order to understand the mechanisms of their $\mathrm{T}$ cell responses. At 10 weeks gestation thymic $\mathrm{T}$ cells proliferate in response to the mitogen phytohaemagglutinin (PHA) and histocompatibility antigens. ${ }^{136} 137$ Peripheral blood mononuclear cell (PBMC) proliferative responses to PHA can be detected by 17 weeks and increase with gestational age. ${ }^{62}$ Fetal PBMC proliferative responses to inhaled and dietary allergens are detectable at 22 weeks gestation and also increase with gestational age. ${ }^{63}{ }^{133}$ How these proliferative responses are generated when it is known that most circulating fetal and neonatal $T$ cells are of the naive phenotype is not known. In one study PBMC from fetuses whose mothers had been exposed to birch tree pollen beyond the 22 nd week of pregnancy had a significantly higher proliferative response to birch tree pollen than fetuses whose mothers were not exposed, suggesting that maternal allergen exposure "primes" fetal $\mathrm{T}$ cells. ${ }^{63}$ The critical period for exposure of the fetus to allergens may be from five to seven months of gestation. ${ }^{138}$ The existence of fetally derived allergen reactive $T$ cells in cord blood has been demonstrated, ${ }^{139}$ but transplacental transfer of allergens or peptides as a mechanism for sensitising fetal $\mathrm{T}$ cells in utero has not been proved.

Proliferative responses of cord blood mononuclear cells (CBMC) to inhaled and food allergens have been reported in some infants. ${ }^{140-144}$ In one study lymphoproliferative responses to HDM and OVA were present in close to half of the newborn infants tested. ${ }^{145}$ In another recent study most of the newborn infants had positive lymphoproliferative responses to at least one common inhaled or food allergen. ${ }^{139}$ The frequencies of the responses were comparable in neonates with and without a family history of atopy. ${ }^{139} 140145$ Proliferative responses to food allergens decreased during the first year of life, while responses to inhaled allergens persisted. ${ }^{146}$ Cord blood lymphoproliferative responses to food or inhaled allergens may predict the subsequent development of allergic disorders in early childhood. ${ }^{142} 144147 \mathrm{In}$ children who developed allergic disease by one year of age proliferative responses to perennial inhalant and food allergens were significantly lower at six months than at birth. ${ }^{147}$ Analysis of allergen specific $\mathrm{T}$ cells from such children would test the hypothesis that induction of tolerance or the movement of sensitised cells to sites of allergen exposure had occurred.

Cross sectional studies suggest that lymphoproliferative responses to inhaled allergens increase between infancy and adulthood. ${ }^{141} 148$ In one study specific $T$ cell reactivity to HDM was seen in the majority of two and three year old children; the lymphoproliferation results were similar in atopic and non-atopic children. ${ }^{149}$ Many adults have aeroallergen specific $\mathrm{T}$ cell reactivity demonstrable in vitro. ${ }^{148} 150$ Allergen specific CD4+ Th clones can be isolated from peripheral blood lymphocytes of both atopic adults and non-atopic controls; however, the cytokine pattern of the clones is Th2-like (IL-4, IL-5) in atopic adults and Th1-like (IL-2, IFN- $\gamma$ ) in non-atopic controls. ${ }^{64}{ }^{150-152}$ The cytokine profiles of allergen specific lymphocytes in neonates and young children are beginning to be elucidated. ${ }^{139} 140146$ In summary, cord blood lymphocyte proliferation studies show that some neonates have $\mathrm{T}$ cells capable of recognising specific allergens. How allergen specific $T$ cells in neonates are related to the subsequent development of asthma in childhood is the focus of current investigation.

\section{Th1/Th2 effector cells and cytokines in neonates}

Pregnancy is considered a Th2 state ${ }^{65}$ and there is some evidence that the neonatal immune response is biased toward the Th2 type. If a neonatal Th2 bias exists, it is not clear whether it represents persistence of the Th2 state of pregnancy or an immune system which has not yet encountered sufficient antigenic stimulation. Neonatal CD4+ $\mathrm{T}$ cells are similar to naive adult $\mathrm{T}$ cells in their ability to release sufficient IL-4 at priming to support clonal expansion into Th2 cells. ${ }^{153} 154$ However, naive cord blood $\mathrm{T}$ cells are much more responsive than adult naive $\mathrm{T}$ cells to IL- 4 stimulation, a characteristic which might help to promote a $\mathrm{Th} 2$ immune response in neonates. ${ }^{135} \mathrm{~A}$ Th2 bias may be more pronounced in infants with family histories of atopy or in infants who subsequently develop allergic manifestations. Allergen specific $\mathrm{T}$ cell clones generated from CBMC of newborn infants with atopic parents produced more IL-4 and IL-5 than T cells 
from those with non-atopic parents; enhanced Th2 cytokine production correlated with atopic manifestations at the age of three. ${ }^{155}$ Allergen stimulation of CBMC led to increases in IL-5 and IFN- $\gamma$ mRNA production in a proportion of neonates, regardless of family history of atopy; by 18 months, however, a mixed Th1/Th2 (IL-5 and IFN- $\gamma$ ) response to OVA and HDM allergens was observed only in children with a family history of atopy. ${ }^{145}$ OVA or mitogen stimulated CBMC produced IL10 , an IFN- $\gamma$ inhibitory cytokine. In a recent study cord blood $\mathrm{T}$ cell responses to HDM or OVA allergens generated the Th2 cytokines IL-4, IL-5, and IL-9 mRNA as well as IL-10 and IL-13 protein, regardless of the infant's family history of allergy. ${ }^{139}$ In a prospective study of children from birth until the age of two inhaled allergen stimulated CBMC produced IL-4, IL-5 and IL-9 (mRNA), IL-6, IL-10, and IL-13 (protein) but very little IFN- $\gamma$ (mRNA or protein). ${ }^{146}$ Interestingly, the Th2 allergen specific responses were lower in neonates who later developed atopic disease than in those who did not become atopic. Allergen specific cytokine production changed with age: between birth and two years IL-4 mRNA production decreased in non-atopic children but persisted in atopic children; IFN- $\gamma$ mRNA production increased significantly between birth and six months in non-atopic children but not in atopic children. ${ }^{146}$ Whether absolute levels of Th1 and Th2 cytokines are significantly different in atopic and non-atopic children at the age of two is less clear. A slightly different pattern of allergen specific $T$ cell cytokine expression was found by the same group in a different study, with increasing Th1 and Th2 cytokine production between birth and the age of two in atopic children. ${ }^{140} \mathrm{~A}$ mixed Th1/Th2 cytokine response to allergen stimulation in young children has been associated with atopy: by the age of five years PBMC from children with a positive skin prick test to HDM displayed an allergen specific mixed Th1/Th2 response (IL-4, IL-5, IFN- $\gamma$ mRNA) while PBMC from skin prick test negative controls produced only the Th1 cytokine IFN- $\gamma$ mRNA. ${ }^{156}$

Further evidence that the immune system of the neonate might be biased toward Th2 responses comes from data indicating that the capacity to produce IFN- $\gamma$ is low during infancy. ${ }^{157} 158$ Activated CBMC produce less IL-12 and IFN- $\gamma$ than adult PBMC. ${ }^{159}$ Neonatal $\mathrm{T}$ cells produce less IFN- $\gamma$ and IL-4 after polyclonal stimulation than adult T cells. ${ }^{160}{ }^{161}$ IFN- $\gamma$ producing $T$ cell populations increase with age, correlating with memory surface antigen expression and increased antigen exposure. ${ }^{162}$ Thus, the reduced capacity to produce IFN- $\gamma$ in infancy is probably due in part to lack of antigenic experience.

Additional studies suggest that reduced IFN- $\gamma$ production is associated with a genetic predisposition to atopy or to the development of atopy in early childhood. IFN- $\gamma$ production by PHA stimulated CBMC was lower in neonates with a family history of atopy. ${ }^{163}$ The development of atopic eczema at one year of age was associated with decreased PBMC IFN- $\gamma$ production in response to a dietary allergen in a study of neonates with an atopic parent. ${ }^{144}$ Reduced IFN- $\gamma$ production by food allergen stimulated CBMC was associated with an increased risk of allergic disorders, primarily atopic dermatitis, at age six in a prospective study of 21 infants. ${ }^{164}$ The cytokine response to inhaled allergens was not tested. Low IL-2 and IFN- $\gamma$ production by mitogen stimulated lymphocytes at the age of nine months has been associated with development of skin test reactivity to aeroallergens at the age of six years. ${ }^{165}$ Children who developed atopic symptoms or a positive skin prick test at one year had significantly lower cord blood IFN- $\gamma$ secretion at birth than children who did not develop atopy. ${ }^{166} \mathrm{CD} 4+\mathrm{T}$ cell clones from children up to the age of four years produced less IFN- $\gamma$ than those from adults; production was lowest in children from allergic families. ${ }^{167}$ There is decreased production of IFN- $\gamma$ and increased production of IL- 6 by mitogen stimulated CBMC of neonates with a family history of allergy. ${ }^{168}$

In summary, studies to date suggest that stimulation of CBMC with allergens in vitro leads predominantly to Th2 cytokine production. During the first years of life there appear to be differences in allergen specific PBMC cytokine production between atopic and nonatopic children. Non-atopic children show a decrease in Th2 responses and an increase in Th1 responses, while atopic children develop increasing $\mathrm{Th} 2$ or mixed $\mathrm{Th} 1 / \mathrm{Th} 2$ responses. Allergen specific cytokine production may be different at birth in infants who will later develop atopy than in those who will not develop atopy. The capacity to produce IFN- $\gamma$ is lower in infants than adults and may be lowest in infants with atopy or a genetic predisposition to atopy. While having the potential to greatly expand our knowledge of the developing immune system, there are limitations to these studies. These limitations include differences in detecting mRNA versus protein cytokine levels, whether in vitro stimulation reflects the in vivo encounter of antigen in the airway, and the applicability of analyses of PBMC to pulmonary processes. There are obvious limitations in our ability to study pulmonary inflammatory cells from infants and young children more directly. ${ }^{12}$

Despite the data which suggest a primarily Th2 type immune response in the neonate, studies of congenital infections demonstrate that some fetuses are capable of generating a Th1 type immune response against certain pathogens. HIV specific cytotoxic T cells have been detected in a congenitally infected neonate. ${ }^{169}$ Fetal $\mathrm{T}$ cells can be primed to HIV in utero, and HIV specific Th immunity may be protective in neonates. ${ }^{170}$ It has been hypothesised that the reduced incidence of certain respiratory infections during infancy and young childhood may delay the switch from the Th2 state of prenatal and neonatal life to the Th1 state of the normal adult immune system. ${ }^{116}$ The interaction between childhood viral respiratory illnesses and asthma, however, 
is quite complex. Respiratory viral infections can stimulate either Th1 or Th2 immune responses. ${ }^{171-174}$ Respiratory syncytial virus (RSV) bronchiolitis in childhood, for example, is associated with $\operatorname{IgE}$ production, airway inflammation, BHR, and chronic wheezing later in life. ${ }^{175}$ The balance between Th1 and Th2 cytokines, rather than polarised Th1 or Th2 responses, is probably critical in determining the immune response to environmental allergens and pathogens in early life. The host and antigen factors responsible for an imbalance of Th1 and Th2 cytokines, leading to autoimmunity or allergic disorders, remain undefined.

\section{Prevention of childhood asthma}

Most cases of childhood asthma begin during infancy. Six year old children who wheeze already have altered lung function. ${ }^{61}$ Interventions designed to prevent asthma should therefore begin soon after birth. ${ }^{86}$ Maternal smoking during pregnancy is associated with reduced pulmonary function in infants and children. There is a clear association between postnatal exposure to tobacco smoke and increased wheezing and asthma in children. ${ }^{88} 176$ Maternal smoking cessation is therefore a prenatal intervention likely to reduce asthma in children. ${ }^{177}$ Several studies have shown that allergen avoidance can be effective in preventing asthma exacerbations or ameliorating asthma symptoms. ${ }^{688} 178$ Reducing exposure to indoor allergens during infancy and early childhood may decrease allergic sensitisation and asthma. Reducing maternal prenatal allergen exposure can reduce or delay atopy but does not decrease asthma in children. ${ }^{177}{ }^{179-181}$ Ongoing studies are evaluating the effect on childhood asthma of aeroallergen avoidance from 18 weeks gestation through the first year of life. $^{49182}$ As we have seen, immune responses to inhaled and dietary allergens have been observed in neonates and young children, regardless of their atopic status. Early environmental exposures may in fact be critical for the proper development of the immune system, including the development of tolerance to ubiquitous non-pathogenic antigens. Determining which environmental exposures early in life lead to protective immunity and which are potentially detrimental is an area of active research.

The use of vaccines, Th1 selective adjuvants, or immunotherapy has been proposed in order to induce allergen specific Th1 memory development in early childhood. ${ }^{116}$ In a murine model intranasal BCG vaccine prevented allergen induced pulmonary inflammation, concomitant with increased local IFN- $\gamma$ production. ${ }^{183}$ Such strategies, while very interesting, have the potential to cause autoimmune disease or permanently alter the immune response in unforeseen ways. Use of a Th1 driving adjuvant to alter Th2 predominant vaccine specific responses in neonatal mice did not completely restore the normal Th1/Th2 balance and caused significant local toxicity. ${ }^{184} 185$ Tumour necrosis factor $\alpha$ $(T N F-\alpha)$ is a Th1 cytokine which plays a significant role in the pathogenesis of inflam- matory diseases such as sepsis and rheumatoid arthritis. Administration of inhibitors of TNF- $\alpha$ has ameliorated rheumatoid arthritis ${ }^{186}$ but increased mortality from sepsis. ${ }^{187}$ These studies show that manipulation of the immune response through inhibition of cytokines does not always lead to the desired or expected result. Undertaking similar investigations in babies and young children who are at risk of developing asthma but still healthy would require special precautions.

\section{Conclusions/future directions}

Asthma causes significant morbidity in children. Its prevalence and severity have increased in the developed world over the past 40 years. Allergic sensitisation appears to play an important role in childhood asthma. Recent studies have found evidence for perinatal $T$ cell responses to inhaled allergens and allergen specific Th2-like cytokine expression in neonates. ${ }^{139} 146$ The questions of why hypersensitivity to airborne allergens develops and why only some allergic children become asthmatic have not yet been answered. There are probably multiple genetic and environmental factors which determine whether the clinical atopic or asthmatic phenotype is expressed in an individual child. Future studies should focus on prospectively correlating a child's genetic predisposition to atopy or asthma with his or her exposure to allergens, allergen specific lymphocyte proliferation, and cytokine profiles and subsequent development of atopy or asthma. Investigating the cellular and molecular mechanisms of $\mathrm{T}$ cell responses which lead to asthma is critical. There is increasing evidence that co-stimulatory molecules, including CD28/B7/CTLA4 and CD40/CD40L, and transcription factors play key roles in the pathogenesis of chronic inflammatory diseases such as asthma. Understanding the immune response to allergens in early life may allow us to develop strategies for preventing childhood asthma.

The authors gratefully acknowledge Doctors David Perkins, David Mark, Adrienne Randolph, Christopher Fanta, Diane Gold, John Hanrahan, Scott Weiss, and Bonnie Bermas for their critical reading of the manuscript. This work was supported by NIH R01 HL56723 (PWF).

1 Gergen PJ, Mullally DI, Evans R. National survey of prevalence of asthma among children in the United States, 1976 to 1980 . Pediatrics $1988 ; 81: 1-7$

2 Croner S, Kjellman NI Natural history of bronchial asthm in childhood. A prospective study from birth up to $12-14$ years of age. Allergy 1992;47:150-7.

3 Yunginger JW, Reed CE, O'Connell EJ, et al. A communitybased study of the epidemiology of asthma. Incidence rates, 1964-1983. Am Rev Respir Dis 1992;146:888-94.

4 Boner AL, Bodini A, Piacentini GL. Environmental allergens and childhood asthma. Clin Exp Allergy 1998;28: $76-81$

5 Sears MR, Burrows B, Flannery EM, et al. Relation between airway responsiveness and serum IgE in children with asthma and in apparently normal children. $N$ Engl $f \mathrm{Med}$ 1991;325:1067-71.

6 Platts-Mills TA, Sporik RB, Chapman MD, et al. The role of domestic allergens. Ciba Found Symp 1997;206:173-85.

7 Holgate ST. Asthma: a dynamic disease of inflammation and repair. Ciba Found Symp 1997;206:5-28.

8 Vollmer WM, Osborne ML, Buist AS. 20-year trends in the prevalence of asthma and chronic airflow obstruction in an HMO. Am f Respir Crit Care Med 1998;157:1079-84.

9 Azzawi M, Bradley B, Jeffery PK, et al. Identification of activated $\mathrm{T}$ lymphocytes and eosinophils in bronchial biopsies in stable atopic asthma. Am Rev Respir Dis 1990;142: 1407-13. 
10 Wardlaw AJ, Dunnette S, Gleich GJ, et al. Eosinophils and mast cells in bronchoalveolar lavage in subjects with mild asthma. Relationship to bronchial hyperreactivity. Am Rev Respir Dis 1988;137:62-9.

11 Corrigan CJ, Kay AB. CD4 T-lymphocyte activation in acute severe asthma. Relationship to disease severity and atopic status. Am Rev Respir Dis 1990;141:970-7.

12 Warner JO, Marguet C, Rao R, et al. Inflammatory mechanisms in childhood asthma. Clin Exp Allergy 1998;28:71-5.

13 Wills-Karp M, Luyimbazi J, Xu X, et al. Interleukin-13. central mediator of allergic asthma. Science 1998;282: 2258-61

14 Grunig G, Warnock M, Wakil AE, et al. Requirement for IL-13 independently of IL-4 in experimental asthma. Science 1998;282:2261-3.

15 Hamid Q, Azzawi M, Ying S, et al. Expression of mRNA for interleukin-5 in mucosal bronchial biopsies from asthma. $f$ Clin Invest 1991;87:1541-6.

16 Corrigan CJ, Kay AB. T cells and eosinophils in the pathogenesis of asthma. Immunol Today 1992;13:501-7.

17 Gerblich AA, Salik H, Schuyler MR. Dynamic T-cell changes in peripheral blood and bronchoalveolar lavage after antigen bronchoprovocation in asthmatics. Am Rev Respir Dis 1991;143:533-7.

18 Robinson DS, Hamid Q, Ying S, et al. Predominant TH2-like bronchoalveolar T-lymphocyte population in atopic asthma. N Engl F Med 1992;326:298-304.

19 Chretien I, Pene J, Briere F, et al. Regulation of human IgE synthesis. I. Human IgE synthesis in vitro is determined by the reciprocal antagonistic effects of interleukin 4 and interferon-gamma. Eur 7 Immunol 1990;20:243-51.

20 Corrigan CJ, Hamid Q, North J, et al. Peripheral blood CD4 but not CD8 $\mathrm{T}$ lymphocytes in patients with exacerbation of asthma transcribe and translate messenger RNA encoding cytokines which prolong eosinophil survival in the context of a Th2-type pattern: effect of glucocorticoid therapy. Am f Respir Cell Mol Biol 1995;12:567-78.

21 Del Prete GF, De Carli M, D'Elios MM, et al. Allergen exposure induces the activation of allergen-specific Th2 cells in the airway mucosa of patients with allergic respiratory disorders. Eur F Immunol 1993;23:1445-9.

22 Punnonen J, Yssel H, de Vries JE. The relative contribution of IL-4 and IL-13 to human IgE synthesis induced by activated CD4+ or CD8+ $\mathrm{T}$ cells. F Allergy Clin Immunol 1997; 100:792-801.

23 Kay AB. T cells as orchestrators of the asthmatic response. Ciba Found Symp 1997;206:56-67.

24 Krug N, Madden J, Redington AE, et al. T-cell cytokine profile evaluated at the single cell level in BAL and blood in allergic asthma. Am F Respir Cell Mol Biol 1996;14:319-26.

25 Hessel EM, Van Oosterhout AJ, Van Ark I, et al. Development of airway hyperresponsiveness is dependent on interferon-gamma and independent of eosinoph infiltration. Am f Respir Cell Mol Biol 1997;16:325-34.

26 Mueller DL, Jenkins MK, Schwartz RH. Clonal expansion versus functional clonal inactivation: a costimulatory versus functional clonal inactivation: a costimulatory signalling pathway determines the outcome of T cell antigen

27 Schwartz RH. A cell culture model for T lymphocyte clonal anergy. Science 1990;248:1349-56.

28 Walunas TL, Lenschow DJ, Bakker CY, et al. CTLA-4 can function as a negative regulator of $\mathrm{T}$ cell activation. Immu nity 1994;1:405-13.

29 Walunas TL, Bakker CY, Bluestone JA. CTLA-4 ligation blocks CD28-dependent $\mathrm{T}$ cell activation. 7 Exp Med 1996;183:2541-50.

30 Krummel MF, Allison JP. CD28 and CTLA-4 have opposing effects on the response of $\mathrm{T}$ cells to stimulation. $\mathcal{F}$ Exp Med 1995; 182:459-65.

31 Krummel MF, Allison JP. CTLA-4 engagement inhibits IL-2 accumulation and cell cycle progression upon activaIL-2 accumulation and cell cycle progression upon act
tion of resting T cells. F Exp Med 1996;183:2533-40.

32 Hutloff A, Dittrich AM, Beier KC, et al. ICOS is an inducible T-cell co-stimulator structurally and functionally related to CD28. Nature 1999;397:263-6.

33 Van Kooten C, Banchereau J. CD40-CD40 ligand: a multifunctional receptor-ligand pair. Adv Immunol 1996;61:1-77.

34 Dubey C, Croft M, Swain SL. Costimulatory requirements of naive CD $4+\mathrm{T}$ cells. ICAM-1 or B7-1 can costimulate
naive CD4 T cell activation but both are required for optimum response. F Immunol 1995;155:45-57.

35 Shinde S, Wu Y, Guo Y, et al. CD40L is important for induction of, but not response to, costimulatory activity. ICAM-1 as the second costimulatory molecule rapidly upregulated by CD40L. F Immunol 1996;157:2764-8.

36 Saoulli K, Lee SY, Cannons JL, et al. CD28-independent, Saoulli K, Lee SY, Cannons JL, et al. CD28-independent,
TRAF2-dependent costimulation of resting T cells by 4-1BB ligand. $\mathcal{F}$ Exp Med 1998;187:1849-62.

37 Liu Y, Jones B, Aruffo A, et al. Heat-stable antigen is a costimulatory molecule for CD4 T cell growth. $\mathcal{F}$ Exp Med 1992;175:437-45.

38 DeBenedette MA, Shahinian A, Mak TW, et al. Costimulation of CD28-T lymphocytes by 4-1BB ligand. F Immuno 1997;158:551-9.

39 Drazen J, Finn P, De Sanctis G. mouse models of airway responsiveness: physiological basis of observed outcomes and analysis of selected examples using these outcome indicators. Annu Rev Physiol 1999;61:593-625.

40 Liu Y, Linsley PS. Costimulation of T-cell growth. Curr Opin Immunol 1992;4:265-70.

41 Krinzman SJ, De Sanctis GT, Cernadas M, et al. Inhibition of $\mathrm{T}$ cell costimulation abrogates airway hyperresponsiveness in a murine model. $\mathcal{F}$ Clin Invest 1996;98:2693-9.
42 Van Oosterhout AJ, Hofstra CL, Shields R, et al. Murine CTLA4-IgG treatment inhibits airway eosinophilia and hyperresponsiveness and attenuates IgE upregulation in a murine model of allergic asthma. Am f Respir Cell Mol Biol 1997;17:386-92.

43 Keane-Myers A, Gause WC, Linsley PS, et al. B7-CD28/ CTLA-4 costimulatory pathways are required for the development of $\mathrm{T}$ helper cell 2-mediated allergic airway responses to inhaled antigens. F Immunol 1997;158:2042-9.

44 Tsuyuki S, Tsuyuki J, Einsle K, et al. Costimulation through B7-2 (CD86) is required for the induction of a lung mucosal T helper cell 2 (TH2) immune response and

45 Mark DA, Donovan CE, De Sanctis GT, et al. Both CD80 and CD86 co-stimulatory molecules regulate allergic and CD86 co-stimulatory molecules regulate allergic

pulmonary inflammation. Int Immunol 1998;10:1647-55.
46 Harris N, Peach R, Naemura J, et al. CD80 costimulation is essential for the induction of airway eosinophilia. $f$ Exp
exris N Med 1997;185:177-82.

47 Larche M, Till SJ, Haselden BM, et al. Costimulation through CD86 is involved in airway antigen-presenting cell and $\mathrm{T}$ cell responses to allergen in atopic asthmatics. $\mathcal{F}$ Immunol 1998;161:6375-82.

48 Agea E, Forenza N, Piattoni S, et al. Expression of B7 co-stimulatory molecules and CD1a antigen by alveolar macrophages in allergic bronchial asthma. Clin Exp Allergy 1998;28:1359-67.

49 Warner JA, Jones CA, Williams TJ, et al. Maternal programming in asthma and allergy. Clin Exp Allergy 1998;28:35-8.

50 Martinez FD. Maternal risk factors in asthma. Ciba Found Symp 1997;206:233-9.

51 Martinez FD, Wright AL, Holberg CJ, et al. Maternal age as a risk factor for wheezing lower respiratory illnesses in the first year of life. Am F Epidemiol 1992;136:1258-68.

52 Anderson HR, Bland JM, Patel S, et al. The natural history of asthma in childhood. $\mathcal{f}$ Epidemiol Community Health 1986;40:121-9.

53 Schwartz J, Gold D, Dockery DW, et al. Predictors of asthma and persistent wheeze in a national sample of children in the United States. Association with social class, perinatal events, and race. Am Rev Respir Dis 1990;142:555-62.

54 Martinez FD, Cline $M$, Burrows B. Increased incidence of asthma in children of smoking mothers. Pediatrics 1992;89:21-6.

55 Weitzman $M$, Gortmaker S, Walker DK, et al. Maternal smoking and childhood asthma. Pediatrics 1990;85:505-11.

56 Oliveti JF, Kercsmar CM, Redline S. Pre- and perinatal risk factors for asthma in inner city African-American children Am F Epidemiol 1996;143:570-7.

57 Halonen M, Stern D, Taussig LM, et al. The predictive relationship between serum IgE levels at birth and subsequent incidences of lower respiratory illnesses and eczema in infants. Am Rev Respir Dis 1992;146:866-70.

58 Litonjua AA, Carey VJ, Burge HA, et al. Parental history and the risk for childhood asthma. Does mother confer more risk than father? Am $\mathcal{F}$ Respir Crit Care Med 1998;158:176-81.

59 Johnson CC, Ownby DR, Peterson EL. Parental history of atopic disease and concentration of cord blood IgE. Clin Exp Allergy 1996;26:624-9.

60 Magnusson CG. Cord serum IgE in relation to family history and as predictor of atopic disease in early infancy. Allergy 1988;43:241-51.

61 Martinez FD, Wright AL, Taussig LM, et al. Asthma and wheezing in the first six years of life. The Group Health Medical Associates. N Engl f Med 1995;332:133-8.

62 Warner JA, Jones AC, Miles EA, et al. Prenatal origins of asthma and allergy. Ciba Found Symp 1997;206:220-8.

63 Jones AC, Miles EA, Warner JO, et al. Fetal peripheral blood mononuclear cell proliferative responses to mitogenic and allergenic stimuli during gestation. Pediatr Allergy Immunol 1996;7:109-16.

64 Holt PG, Macaubas C. Development of long-term tolerance versus sensitisation to environmental allergens during the perinatal period. Curr Opin Immunol 1997;9:782-7.

65 Wegmann TG, Lin H, Guilbert L, et al. Bidirectional cytokine interactions in the maternal-fetal relationship: is successful pregnancy a TH2 phenomenon? Immunol Today 1993;14:353-6.

66 Dudley DJ, Chen CL, Mitchell MD, et al. Adaptive immune responses during murine pregnancy: pregnancy-induced regulation of lymphokine production by activated T lymphocytes. Am f Obstet Gynecol 1993;168:1155-63.

67 Delassus S, Coutinho GC, Saucier C, et al. Differential cytokine expression in maternal blood and placenta during murine gestation. F Immunol 1994;152:241 1-20.

68 Beer A, Kwak J. Immunology of normal pregnancy. Immunol Allergy Clin North Am 1998;18:249-70.

69 Weinberg ED. Pregnancy-associated depression of cellmediated immunity. Rev Infect Dis 1984;6:814-31.

70 Matthiesen L, Berg G, Ernerudh J, et al. Lymphocyte subsets and mitogen stimulation of blood lymphocytes in normal pregnancy. Am $\mathcal{F}$ Reprod Immunol 1996;35:70-9.

71 Bermas BL, Hill JA. Proliferative responses to recal antigens are associated with pregnancy outcome in women with a history of recurrent spontaneous abortion. $f$ Clin Invest 1997;100:1330-4.

72 Lin H, Mosmann TR, Guilbert L, et al. Synthesis of T helper 2-type cytokines at the maternal-fetal interface. $f$ Immunol 1993;151:4562-73.

73 Raghupathy R. Th1-type immunity is incompatible with successful pregnancy. Immunol Today 1997;18:478-82

74 Jones CA, Williams KA, Finlay-Jones JJ, et al. Interleukin 4 production by human amnion epithelial cells and regulation of its activity by glycosaminoglycan binding. Biol
Reprod 1995;52:839-47. 
75 Cadet P, Rady PL, Tyring SK, et al. Interleukin-10 messenger ribonucleic acid in human placenta: implications of a role for interleukin-10 in fetal allograft protection. $A m g$ Obstet Gynecol 1995;173:25-9.

76 Kapsenberg ML, Hilkens CM, Wierenga EA, et al. The role of antigen-presenting cells in the regulation of allergenspecific T cell responses. Curr Opin Immunol 1998;10:607-13.

77 Campbell DAJ, Lorber MI, Sweeton JC, et al. Breast feeding and maternal-donor renal allografts. Possibly the original

Ever cells from Peyer's patch and spleen induce different cells from Peyer's patch and spleen induce different T helper cell.

79 Harper HM, Cochrane L, Williams NA. The role of small intestinal antigen-presenting cells in the induction of T-cell reactivity to soluble protein antigens: association between aberrant presentation in the lamina propria and oral tolerance. Immunology 1996;89:449-56.

80 Squillace SP, Sporik RB, Rakes G, et al. Sensitization to dus mites as a dominant risk factor for asthma among adolescents living in central Virginia. Multiple regression analysis of a population-based study. Am $\mathcal{F}$ Respir Crit Care Med 1997;156:1760-4.

81 Sporik R, Ingram JM, Price W, et al. Association of asthma with serum IgE and skin test reactivity to allergens among children living at high altitude. Tickling the dragon's breath. Am f Respir Crit Care Med 1995;151:1388-92.

82 Rosenstreich DL, Eggleston P, Kattan M, et al. The role of cockroach allergy and exposure to cockroach allergen in causing morbidity among inner-city children with asthma. N Engl f Med 1997;336:1356-63.

83 Call RS, Smith TF, Morris E, et al. Risk factors for asthma in inner city children. F Pediatr 1992;121:862-6.

84 Woolcock AJ, Peat JK. Evidence for the increase in asthma worldwide. Ciba Found Symp 1997;206:122-34

85 Morgan WJ, Martinez FD. Risk factors for developing wheezing and asthma in childhood. Pediatr Clin North Am 1992;39:1185-203.

86 Wright AL, Taussig LM. Lessons from long-term cohort studies. Childhood asthma. Eur Respir f Suppl 1998;27:17 $22 \mathrm{~S}$.

87 Sporik R, Holgate ST, Platts-Mills TA, et al. Exposure to house-dust mite allergen (Der $p \mathrm{I})$ and the development of asthma in childhood. A prospective study. $N$ Engl $\mathcal{F}$ Med 1990;323:502-7.

88 Peat J, Bjorksten B. Primary and secondary prevention of allergic asthma. Eur Respir f Suppl 1998;27:28-34S.

89 Zimmerman B, Feanny S, Reisman J, et al. Allergy in asthma. I. The dose relationship of allergy to severity of childhood asthma. I Allergy Clin Immunol 1988;81:63-70.

90 Peat JK, Salome CM, Woolcock AJ. Longitudinal changes in atopy during a 4-year period: relation to bronchial hyperresponsiveness and respiratory symptoms in a population sample of Australian schoolchildren. F Allergy Clin Immunol 1990;85:65-74.

91 Clough JB, Williams JD, Holgate ST. Effect of atopy on the natural history of symptoms, peak expiratory flow, and natural history of symptoms, peak expiratory flow, and bronchial responsiveness in 7-and 8-year-old children with
cough and wheeze. A 12-month longitudinal study. Am Rev Cough and wheeze. A 12-mont Dis 1991;143:755-60.

92 Strachan DP. Is allergic disease programmed in early life? Clin Exp Allergy 1994;24:603-5.

93 Yemaneberhan H, Bekele Z, Venn A, et al. Prevalence of wheeze and asthma and relation to atopy in urban and rura Ethiopia. Lancet 1997;350:85-90.

94 Leung R, Ho P. Asthma, allergy, and atopy in three south-east Asian populations. Thorax 1994;49:1205-10.

95 Briere F, Servet-Delprat C, Bridon JM, et al. Human interleukin 10 induces naive surface immunoglobulin $\mathrm{D}+$ (sIgD+) B cells to secrete $\operatorname{IgG}_{1}$ and $\mathrm{IgG}_{3}$. F Exp Med 1994; 179:757-62.

96 Servet-Delprat C, Bridon JM, Djossou O, et al. Delayed $\mathrm{IgG}_{2}$ humoral response in infants is not due to intrinsic IgG $_{2}$ humoral response in infants is not due to
or B cell defects. Int Immunol 1996;8:1495-502.

97 Punnonen J, Aversa G, de Vries JE. Human pre-B cells differentiate into Ig-secreting plasma cells in the presence of interleukin 4 and activated CD4+ $\mathrm{T}$ cells or thei membranes. Blood 1993;82:2781-9.

98 Punnonen J, de Vries JE. IL-13 induces proliferation, Ig isotype switching, and Ig synthesis by immature human fetal B cells. F Immunol 1994;152:1094-102.

99 Paryani SG, Arvin AM. Intrauterine infection with varicella-zoster virus after maternal varicella. $N$ Engl f Med 1986;314:1542-6.

100 Pinon JM, Toubas D, Marx C, et al. Detection of specific immunoglobulin $\mathrm{E}$ in patients with toxoplasmosis. $\mathcal{f}$ Clin Microbiol 1990;28:1739-43.

101 Lewis D. Cellular immunity of the human fetus and neonate. Immunol Allergy Clin North Am 1998;18:291-328.

102 von Hoegen P, Sarin S, Krowka JF. Deficiency in T cell responses of human fetal lymph node cells: a lack of accessory cells. Immunol Cell Biol 1995;73:353-61.

103 Mariani F, Price JF, Kemeny DM. The IgG subclass antibody response to an inhalant antigen (Dermatophagoides pteronyssinus) during the first year of life: evidence for early stimulation of the immune system following natural exposure. Clin Exp Allergy 1992;22:29-33.

104 Rowntree S, Platts-Mills TA, Cogswell JJ, et al. A subclass IgG4-specific antigen-binding radioimmunoassay (RIA) comparison between IgG and IgG4 antibodies to food and inhaled antigens in adult atopic dermatitis after desensitizainhaled antigens in adult atopic dermatitis after desensitization treatment and during development of antibody re-
sponses in children. $\mathcal{F}$ Allergy Clin Immunol 1987;80:622-30.
105 Homburger HA, Mauer K, Sachs MI, et al. Serum IgG4 concentrations and allergen-specific IgG4 antibodies compared in adults and children with asthma and nonallergic subjects. F Allergy Clin Immunol 1986;77:427-34.

106 Kemeny DM, Urbanek R, Ewan P, et al. The subclass of IgG antibody in allergic disease: II. The IgG subclass of antibodies produced following natural exposure to dust mite and grass pollen in atopic and non-atopic individuals. Clin Exp Allergy 1989;19:545-9.

107 Devey ME, Beckman S, Kemeny DM. The functional affinities of antibodies of different IgG subclasses to dietary antigens in mothers and their babies. Clin Exp Immunol 1993;94:117-21.

108 Okahata H, Nishi Y, Mizoguchi N, et al. Development of serum Dermatophagoides farinae-, ovalbumin- and lactalbumin-specific IgG, IgG1, IgG4, IgA and $\operatorname{IgM}$ in children with bronchial asthma/allergic rhinitis or atopic dermatitis. Clin Exp Allergy 1990;20:39-44.

109 Hansen LG, Host A, Halken S, et al. Cord blood IgE. II. Prediction of atopic disease. A follow-up at the age of 18 months. Allergy 1992;47:397-403.

110 Kjellman NI, Croner S. Cord blood IgE determination for allergy prediction: a follow-up to seven years of age in allergy prediction: a follow-up to seven years

111 Hide DW, Arshad SH, Twiselton R, et al. Cord serum IgE: an insensitive method for prediction of atopy. Clin Exp Allergy 1991;21:739-43.

112 Bergmann RL, Edenharter G, Bergmann KE, et al. Predictability of early atopy by cord blood-IgE and parental history. Clin Exp Allergy 1997;27:752-60.

113 Holt PG. Immunoprophylaxis of atopy: light at the end of the tunnel? Immunol Today 1994;15:484-9.

114 Hattevig G, Kjellman B, Bjorksten B. Appearance of IgE antibodies to ingested and inhaled allergens during the first 12 years of life in atopic and non-atopic children. Pediatr Allergy Immunol 1993; 4:182-6.

115 Rowntree S, Cogswell JJ, Platts-Mills TA, et al. Development of IgE and IgG antibodies to food and inhalant allergens in children at risk of allergic disease. Arch Dis Child 1985;60:727-35

116 Holt PG, Sly PD. Allergic respiratory disease: strategic targets for primary prevention during childhood. Thorax 1997;52:1-4

117 Byrne JA, Stankovic AK, Cooper MD. A novel subpopulation of primed $\mathrm{T}$ cells in the human fetus. F Immunol 1994; 152:3098-106.

118 Peakman M, Buggins AG, Nicolaides KH, et al. Analysis of lymphocyte phenotypes in cord blood from early gestation fetuses. Clin Exp Immunol 1992;90:345-50.

119 Frenkel L, Bryson YJ. Ontogeny of phytohemagglutinininduced gamma interferon by leukocytes of healthy infants and children: evidence for decreased production in infants younger than 2 months of age. $\mathcal{F}$ Pediatr 1987;111 97-100.

120 Hannet I, Erkeller-Yuksel F, Lydyard P, et al. Developmental and maturational changes in human blood lymphocyte subpopulations. Immunol Today 1992;13:215.

121 Sanders ME, Makgoba MW, Shaw S. Human naive and memory T cells: reinterpretation of helper-inducer and memory T cells: reinterpretation of helper-inducer and

122 Burchett SK, Corey L, Mohan KM, et al. Diminished interferon-gamma and lymphocyte proliferation in neonatal and postpartum primary herpes simplex virus infection J Infect Dis 1992;165:813-8.

123 Starr SE, Tolpin MD, Friedman HM, et al. Impaired cellular immunity to cytomegalovirus in congenitally infected children and their mothers. F Infect Dis 1979;140:500-5.

124 Hassan J, Reen DJ. Reduced primary antigen-specific T-cell precursor frequencies in neonates is associated with deficient interleukin-2 production. Immunology 1996;87: deficient

125 Hassan J, Reen DJ. Cord blood CD4+ CD45RA+ T cells achieve a lower magnitude of activation when compared with their adult counterparts. Immunology 1997;90:397401 .

126 Brugnoni D, Airo P, Graf D, et al. Ineffective expression of CD40 ligand on cord blood T cells may contribute to poo immunoglobulin production in the newborn. Eur f Immunol 1994;24:1919-24.

127 Durandy A, De Saint B, Lisowska-Grospierre B, et al. Undetectable CD40 ligand expression on T cells and low B cell responses to CD40 binding agonists in human newborns. F Immunol 1995;154:1560-8.

128 Nonoyama S, Penix LA, Edwards CP, et al. Diminished expression of CD40 ligand by activated neonatal T cells. $\mathscr{F}$ Clin Invest 1995;95:66-75.

129 Splawski JB, Nishioka J, Nishioka Y, et al. CD40 ligand is expressed and functional on activated neonatal T cells. $\mathcal{F}$ Immunol 1996;156:119-27.

130 Cayabyab M, Phillips JH, Lanier LL. CD40 preferentially costimulates activation of $\mathrm{CD} 4+\mathrm{T}$ lymphocytes. $\mathcal{F}$ Immunol 1994;152:1523-31.

131 Hassan J, O'Neill S, O'Neill LA, et al. Signalling via CD28 of human naive neonatal T lymphocytes. Clin Exp Immunol 1995;102:192-8.

132 Clerici M, DePalma L, Roilides E, et al. Analysis of T helper and antigen-presenting cell functions in cord blood and peripheral blood leukocytes from healthy children of and peripheral blood leukocytes from healthy

133 Holt PG. Primary allergic sensitization to environmental antigens: perinatal $\mathrm{T}$ cell priming as a determinant of responder phenotype in adulthood. F Exp Med 1996;183: 1297-301. 
134 Takahashi N, Imanishi K, Nishida H, et al. Evidence for immunologic immaturity of cord blood T cells. Cord bloo $\mathrm{T}$ cells are susceptible to tolerance induction to in vitro stimulation with a superantigen. F Immunol 1995;155: 5213-9.

135 Early EM, Reen DJ. Antigen-independent responsiveness to interleukin-4 demonstrates differential regulation of newborn human T cells. Eur F Immunol 1996;26:2885-9.

136 Hayward AR. Development of lymphocyte responses and interactions in the

137 Toivanen P, Uksila J, Leino A, et al. Development of mitogen responding T cells and natural killer cells in the
human fetus. Immunol Rev 1981;57:89-105.

138 Van Duren-Schmidt K, Pichler J, Ebner C, et al. Prenatal contact with inhalant allergens. Pediatr Res 1997;41:128-31.

139 Prescott SL, Macaubas C, Holt BJ, et al. Transplacental priming of the human immune system to environmental allergens: universal skewing of initial $\mathrm{T}$ cell responses toward the Th2 cytokine profile. F Immunol 1998;160: 4730-7.

140 Prescott SL, Macaubas C, Smallacombe T, et al. Reciprocal age-related patterns of allergen-specific T-cell immunity in normal vs. atopic infants. Clin Exp Allergy 1998;28:39-44.

141 Holt PG, O'Keeffe P, Holt BJ, et al. T-cell "priming" against environmental allergens in human neonates: sequential deletion of food antigen reactivity during infancy with concomitant expansion of responses to ubiquitous inhalant allergens. Pediatr Allergy Immunol 1995;6:85-90.

142 Kondo N, Kobayashi Y, Shinoda S, et al. Cord blood lymphocyte responses to food antigens for the prediction of allergic disorders. Arch Dis Child 1992;67: 1003-7.

143 Piccinni MP, Mecacci F, Sampognaro S, et al. Aeroallergen sensitization can occur during fetal life. Int Arch Allergy Immunol 1993;102:301-3.

144 Warner JA, Miles EA, Jones AC, et al. Is deficiency of interferon gamma production by allergen triggered cord blood cells a predictor of atopic eczema? Clin Exp Allergy 1994;24:423-30.

145 Prescott SL, Macaubes C, Yabuhara A, et al. Developing patterns of $\mathrm{T}$ cell memory to environmental allergens in the first two years of life. Int Arch Allergy Immunol 1997;113: 75-9.

146 Prescott SL, Macaubas C, Smallacombe T, et al. Development of allergen-specific T-cell memory in atopic and normal children Lancet 1999;353:196-200.

147 Miles EA, Warner JA, Jones AC, et al. Peripheral blood mononuclear cell proliferative responses in the first year of life in babies born to allergic parents. Clin Exp Allergy 1996;26:780-8

148 Upham JW, Holt BJ, Baron-Hay MJ, et al. Inhalan allergen-specific T-cell reactivity is detectable in close to $100 \%$ of atopic and normal individuals: covert response are unmasked by serum-free medium. Clin Exp Allergy 1995;25:634-42.

149 Bjorksten B, Holt BJ, Baron-Hay MJ, et al. Low-level exposure to house dust mites stimulates T-cell responses during early childhood independent of atopy. Clin Exp Allergy 1996;26:775-9.

150 Romagnani S. Induction of $\mathrm{TH} 1$ and $\mathrm{TH} 2$ responses: a key role for the 'natural' immune response? Immunol Today 1992;13:379-81.

151 Wierenga EA, Snoek M, de Groot C, et al. Evidence for compartmentalization of functional subsets of CD2+ T lymphocytes in atopic patients. F Immunol 1990;144: 4651-6.

152 Parronchi P, Macchia D, Piccinni MP, et al. Allergen- and bacterial antigen-specific T-cell clones established from atopic donors show a different profile of cytokin production. Proc Natl Acad Sci USA 1991;88:4538-42.

153 Yang LP, Byun DG, Demeure CE, et al. Default development of cloned human naive CD4 $\mathrm{T}$ cells into interleukin-4 and interleukin-5 producing effector cells. Eur F Immunol 1995;25:3517-20.

154 Demeure CE, Yang LP, Byun DG, et al. Human naive CD4 $\mathrm{T}$ cells produce interleukin- 4 at priming and acquire a Th2 phenotype upon repetitive stimulations in neutral condiphenotype upon repetitive stimulations
tions. Eur f Immunol 1995;25:2722-5.

155 Piccinni MP, Beloni L, Giannarini L, et al. Abnormal production of $\mathrm{T}$ helper 2 cytokines interleukin-4 and interleukin- 5 by $T$ cells from newborns with atopic parents Eur F Immunol 1996;26:2293-8.

156 Yabuhara A, Macaubas C, Prescott SL, et al. TH2 polarized immunological memory to inhalant allergens in atopics is established during infancy and early childhood. Clin Exp Allergy 1997;27:1261-9.

157 Taylor S, Bryson YJ. Impaired production of gammainterferon by newborn cells in vitro is due to a functionally immature macrophage. f Immunol 1985;134:1493-7.

158 Wilson CB, Westall J, Johnston L, et al. Decreased production of interferon-gamma by human neonatal cells. Intrinsic and regulatory deficiencies. F Clin Invest 1986;77: 860-7.

159 Lee SM, Suen Y, Chang L, et al. Decreased interleukin-12 (IL-12) from activated cord versus adult peripheral blood mononuclear cells and upregulation of interferon-gamma, natural killer, and lymphokine-activated killer activity by IL 12 in cord blood mononuclear cells. Blood 1996;88:945-54

160 Lewis DB, Larsen A, Wilson CB. Reduced interferongamma mRNA levels in human neonates. Evidence for an
intrinsic $T$ cell deficiency independent of other genes involved in T cell activation. $\mathcal{F}$ Exp Med 1986;163:1018-23.
161 Lewis DB, Yu CC, Meyer J, et al. Cellular and molecular mechanisms for reduced interleukin 4 and interferongamma production by neonatal T cells. F Clin Invest 1991; 87:194-202.

162 Chipeta J, Komada Y, Zhang XL, et al. CD4+ and CD8+ cell cytokine profiles in neonates, older children, and adults: increasing $\mathrm{T}$ helper type 1 and $\mathrm{T}$ cytotoxic type 1 cell populations with age. Cell Immunol 1998;183:149-56.

163 Rinas U, Horneff G, Wahn V. Interferon-gamma production by cord-blood mononuclear cells is reduced in newborns with a family history of atopic disease and is independent from cord blood IgE-levels. Pediatr Allergy Immunol 1993;4:60-4.

164 Kondo N, Kobayashi Y, Shinoda S, et al. Reduced interferon gamma production by antigen-stimulated cord blood mononuclear cells is a risk factor of allergic disorders: 6-year follow-up study. Clin Exp Allergy 1998;28: 1340-4.

165 Martinez FD, Stern DA, Wright AL, et al. Association of interleukin-2 and interferon-gamma production by blood mononuclear cells in infancy with parental allergy skin test and with subsequent development of atopy. 7 Allergy Clin Immunol 1995;96:652-60.

166 Tang ML, Kemp AS, Thorburn J, et al. Reduced interferon-gamma secretion in neonates and subsequent atopy. Lancet 1994;344:983-5.

167 Holt PG, Clough JB, Holt BJ, et al. Genetic 'risk' for atopy is associated with delayed postnatal maturation of T-cell competence. Clin Exp Allergy 1992;22:1093-9.

168 Liao SY, Liao TN, Chiang BL, et al. Decreased production of IFN gamma and increased production of IL-6 by cord blood mononuclear cells of newborns with a high risk of allergy. Clin Exp Allergy 1996;26:397-405.

169 Pikora CA, Sullivan JL, Panicali D, et al. Early HIV-1 envelope-specific cytotoxic $\mathrm{T}$ lymphocyte responses in vertically infected infants. $\mathcal{F}$ Exp Med 1997;185:1153-61.

170 Clerici M, Sison AV, Berzofsky JA, et al. Cellular immune factors associated with mother-to-infant transmission of HIV. AIDS 1993; 7:1427-33.

171 Cookson WO, Moffatt MF. Asthma: an epidemic in the absence of infection? Science 1997;275:41-2.

172 Schwarze J, Hamelmann E, Bradley KL, et al. Respiratory syncytial virus infection results in airway hyperresponsiveness and enhanced airway sensitization to allergen. 7 Clin Invest 1997;100:226-33.

173 Marbury MC, Maldonado G, Waller L. Lower respiratory illness, recurrent wheezing, and day care attendance. $A m \mathcal{F}$ Respir Crit Care Med 1997;155:156-61.

174 Martinez FD. Role of viral infections in the inception of asthma and allergies during childhood: could they be protective? Thorax 1994;49:1189-91.

175 Sigurs N, Bjarnason R, Sigurbergsson F, et al. Asthma and immunoglobulin E antibodies after respiratory syncytial virus bronchiolitis: a prospective cohort study with virus bronchiolitis: a prospective cohort

176 US Environmental Protection Agency. Respiratory health effects of passive smoking: lung cancer and other disorders. Washington DC: Office of Health and Environmental Assessment, Office of Research and Development, 1992.

177 Hanrahan JP, Halonen M. Antenatal interventions in childhood asthma. Eur Respir F Suppl 1998;27:46-51S.

178 Custovic A, Simpson A, Chapman MD, et al. Allergen avoidance in the treatment of asthma and atopic disorders. Thorax 1998;53:63-72.

179 Chandra RK, Puri S, Suraiya C, et al. Influence of maternal food antigen avoidance during pregnancy and lactation on incidence of atopic eczema in infants. Clin Allergy 1986; 16:563-9.

180 Falth-Magnusson K, Kjellman NI. Allergy prevention by maternal elimination diet during late pregnancy: a 5-year follow-up of a randomized study. 7 Allergy Clin Immuno 1992;89:709-13.

181 Zeiger RS, Heller S, Mellon MH, et al. Effect of combined maternal and infant food-allergen avoidance on development of atopy in early infancy: a randomized study. $\mathcal{F}$ ment of atopy in early infancy: a

182 Schonberger HJ, Van Schayck CP. Prevention of asthma in genetically predisposed children in primary care: from clinical efficacy to a feasible intervention programme. Clin Exp Allergy 1998;28:1325-31.

183 Erb KJ, Holloway JW, Sobeck A, et al. Infection of mice with Mycobacterium bovis-Bacillus Calmette-Guerin (BCG) suppresses allergen-induced airway eosinophilia. F Exp Med 1998;187:561-9.

184 Barrios C, Brandt C, Berney M, et al. Partial correction of the TH2/TH1 imbalance in neonatal murine responses to the $\mathrm{TH} 2 / \mathrm{TH} 1$ imbalance in neonatal murine responses to
vaccine antigens through selective adjuvant effects. Eur $\mathcal{F}$ vaccine antigens through se
Immunol 1996;26:2666-70.

185 Barrios C, Brawand P, Berney M, et al. Neonatal and early life immune responses to various forms of vaccine antigen qualitatively differ from adult responses: predominance of a Th2-biased pattern which persists after adult boosting. Eur F Immunol 1996;26:1489-96.

186 Weinblatt ME, Kremer JM, Bankhurst AD, et al. A trial of etanercept, a recombinant tumor necrosis factor receptor: $F c$ fusion protein, in patients with rheumatoid arthritis receiving methotrexate. N Engl f Med 1999;340:253-9.

187 Fisher CJJ, Agosti JM, Opal SM, et al. Treatment of septic shock with the tumor necrosis factor receptor:fc fusion protein. N Engl f Med 1996;334:1697-702. 